\title{
Meningkatkan Motivasi dan Prestasi Belajar Matematika melalui Model Pembelajaran Think-Pair-Share
}

\author{
Anisa Yustina Sari \\ Program Studi Pendidikan Matematika, Universitas Veteran Bangun Nusantara \\ Email: anisayustinasari@gmail.com
}

\begin{abstract}
Abstrak
Penelitian ini bertujuan untuk meningkatkan motivasi dan prestasi belajar matematika siswa kelas VIIA SMP Negeri 3 Bendosari Sukoharjo tahun ajaran 2015/2016 pada pokok bahasan segiempat melalui model pembelajaran kooperatif tipe TPS (Think-Pair-Share). Subjek dalam penelitian ini adalah seluruh siswa kelas VIIA SMP Negeri 3 Bendosari Sukoharjo, sebanyak 29 siswa. Penelitian ini menggunakan Penelitian Tindakan Kelas (PTK). Penelitian Tindakan ini dilakukan melalui tiga siklus yang menggunakan metode pengumpulan data dengan tes, pengisian angket dan observasi. Tiap-tiap siklus terdiri atas perencanaan, tindakan, pengamatan dan refleksi. Dari penelitian yang telah dilakukan dapat disimpulkan bahwa penerapan model pembelajaran kooperatif tipe Think-Pair-Share dapat meningkatkan motivasi dan prestasi belajar matematika pokok bahasan segiempat pada siswa kelas VIIA SMP Negeri 3 Bendosari Kabupaten Sukoharjo Tahun Pelajaran 2015/2016.
\end{abstract}

Kata kunci : motivasi, prestasi, think-pair-share

\section{Increasing Student Motivation and Mathematical Learning Achievements through Think-Pair-Share Learning Model}

\begin{abstract}
This study aims to increase the motivation and achievement of mathematics learning in class VIIA students of SMP Negeri 3 Bendosari Sukoharjo in the 2015/2016 academic year on the subject of quadrilateral through cooperative learning model type TPS (Think-Pair-Share). The subjects in this study were all students of class VII A of SMP Negeri 3 Bendosari Sukoharjo, as many as 29 students. This study uses Classroom Action Research (CAR). This Action Research was carried out through three cycles that used data collection methods with tests, questionnaires and observations. Each cycle consists of planning, action, observation and reflection. From the research that has been done it can be concluded that the application of the cooperative learning model Think-Pair-Share can increase the motivation and learning achievement of mathematics on the subject matter of quadrilateral in class VIIA students of SMP Negeri 3 Bendosari Sukoharjo District 2015/2016 Academic Year.
\end{abstract}

Keywords : achievement, motivation, think-pair-share

\section{PENDAHULUAN}

Motivasi menurut pendapat Dimyati dan Mudjiono (2013: 80), dipandang sebagai dorongan mental yang menggerakkan dan mengarahkan perilaku manusia, termasuk perilaku belajar. Tinggi rendahnya motivasi belajar siswa dapat dipengaruhi oleh bermacam-macam hal. Jika dikelompokkan lagi dapat diklasifikasikan menjadi dua faktor internal dan eksternal. Seperti yang diungkap oleh Dimyati dan Mudjiono (2013: 97-100) motivasi belajar siswa dapat dipengaruhi oleh cita-cita atau aspirasi siswa, kemampuan siswa, kondisi siswa, kondisi 
lingkungan siswa, unsur-unsur dinamis dalam belajar dan pembelajaran dan upaya guru dalam membelajarkan siswa.

Tinggi rendahnya motivasi belajar siswa berpengaruh terhadap prestasi belajar siswa. Hamdani (2011: 139-144) menuturkan bahwa prestasi belajar dapat dipengaruhi oleh beberapa faktor yang berasal dari luar dan dari dalam diri siswa. Adapun faktor-faktor tersebut sebagai berikut: a. Faktor Internal: 1) Kecerdasan (inteligensi), 2) Jasmani atau fisiologis, 3) Sikap, 4) Minat, 5) Motivasi, 6) Kepercayaan pada diri sendiri, b) Faktor Eksternal: 1) Faktor keluarga, 2) Faktor sekolah, 3) Faktor lingkungan.

Dalam dunia pendidikan Matematika, guru memegang peranan penting dalam mewujudkan tercapainya tujuan pembelajaran. Seorang guru Matematika disamping menjelaskan konsep, prinsip, teorema, guru juga harus mengajarkan Matematika dengan menciptakan kondisi yang baik agar keterlibatan siswa secara aktif dapat berlangsung. Unsur penting dalam pembelajaran Matematika adalah merangsang siswa serta mengarahkan siswa belajar, dimana belajar dapat dirangsang dan dibimbing dengan berbagai metode atau cara yang mengarah pada tujuannya, dan langkah yang tepat adalah dengan menggunakan metode mengajar yang sesuai dengan pokok bahasan yang diajarkan.

Melalui observasi pelaksanaan kegiatan pembelajaran di SMP Negeri 3 Bendosari Sukoharjo pada siswa kelas VIIA khususnya mata pelajaran Matematika, guru masih menggunakan metode pembelajaran yang bersifat tradisional yaitu metode pembelajaran ceramah dan banyak memberikan tugas yang tidak terstruktur dengan baik, dimana guru jarang membahas tugas yang diberikan. Penerapan metode yang demikian menyebabkan siswa merasa jenuh dan bosan.

Perasaan jenuh dan bosan menyebabkan motivasi belajar matematika siswa menjadi rendah. Rendahnya motivasi belajar matematika siswa kelas VIIA terlihat saat pembelajaran matematika berlangsung. Ada 21 atau 72,4\% siswa yang tidak mengerjakan tugas matematika di rumah, dan hanya 6 siswa atau 20,7\% yang berusaha menjawab pertanyaan yang diajukan oleh guru. Rendahnya motivasi belajar matematika dapat mempengaruhi prestasi belajar matematika siswa. Motivasi belajar matematika siswa kelas VIIA yang rendah, menyebabkan prestasi belajar matematika juga rendah.

Rendahnya prestasi belajar matematika kelas VIIA dapat dilihat dari nilai murni UTS semester II pada mata pelajaran Matematika. Siswa hanya memperoleh rata-rata kelas, sebesar 47,44, padahal nilai Kriteria Ketuntasan Minimum (KKM) mata pelajaran matematika adalah 71 dan tidak ada siswa yang mencapai nilai KKM.

Untuk mengatasi kurangnya motivasi dan prestasi belajar siswa dalam pelajaran matematika, maka perlu usaha untuk meningkatkannya. Dalam hal ini penggunaan model 
pembelajaran kooperatif merupakan salah satu alternatif untuk menanamkan konsep dasar yang benar, konkrit dan realistis sehingga siswa lebih mudah mencerna/memahami materi pelajaran sesuai taraf berpikir mereka, sekaligus diharapkan dapat meningkatkan motivasi dan prestasi belajar siswa dalam mata pelajaran matematika. Hal ini didukung oleh pendapat

Penggunaan model pembelajaran yang variatif akan menjadikan siswa lebih tertarik untuk mempelajari pelajaran matematika. Salah satu model pembelajaran yang dapat digunakan adalah dengan model pembelajaran kooperatif tipe Think-Pair-Share.

Model pembelajaran kooperatif, khususnya pembelajaran kooperatif tipe Think-PairShare merupakan pembelajaran yang dapat diterapkan pada pembelajaran matematika karena dalam proses pembelajarannya siswa tidak hanya belajar menghafal atau menghitung tetapi siswa juga belajar bersosialisasi dengan teman sejawat. Dengan menggunakan metode pembelajaran ini diharapkan pada pembelajaran matematika, siswa dapat lebih aktif dalam proses belajar matematika dan nilai belajar siswa dapat mencapai di atas kriteria ketuntasan minimum yang telah ditetapkan yaitu 71 .

Berdasarkan permasalahan di atas, salah satu upaya yang dapat dilakukan untuk mengatasi masalah tersebut adalah menggunakan model pembelajaran kooperatif dalam penyampaian materi pelajaran. Penyampaian materi dengan menggunakan model pembelajaran kooperatif bisa digunakan untuk menciptakan suasana kegiatan belajar dan mengajar yang menyenangkan bagi siswa. Diharapkan dengan suasana yang menyenangkan siswa dapat memahami materi secara maksimal, sehingga bisa meningkatkan motivasi dan prestasi belajar siswa. Atas dasar kejadian tersebut, diduga melalui model pembelajaran kooperatif tipe TPS (Think-Pair-Share) pendidik mampu meningkatkan prestasi dan motivasi belajar matematika pada pokok bahasan Segiempat siswa kelas VIIA SMP Negeri 3 Bendosari Sukoharjo Tahun $2015 / 2016$.

\section{METODE}

Jenis penelitian ini adalah Penelitian Tindakan Kelas (PTK) atau Classroom Action Research (CAR) yang dilakukan secara kolaborasi antara kepala sekolah, guru Matematika, dan peneliti. Penelitian tindakan ditandai dengan adanya perbaikan secara terus menerus sehingga tercapainya sasaran dari penelitian tersebut. Perbaikan tersebut dirancang pada setiap siklus yang dirancang oleh peneliti. PTK bercirikan perbaikan terus menerus sehingga kepuasan peneliti menjadi tolak ukur berhasilnya/berhentinya siklus-siklus tersebut. Menurut Arikunto (2013: 137), secara garis besar terdapat empat tahapan yang lazim dilalui, yaitu: Perencanaan, Pelaksanaan, Pengamatan dan Refleksi. 
Penelitian ini dilaksanakan pada bulan Mei untuk mengetahui seberapa besar pengaruh penggunaan metode pembelajaran kooperatif tipe TPS dapat meningkatkan motivasi dan prestasi belajar siswa dalam menyelesaikan soal segiempat. Dalam penelitian tindakan kelas ini terdiri lebih dari 1 (satu) siklus dan dalam tiap siklusnya meliputi planning (perencanaan), acting (tindakan), observing (pengamatan), dan reflecting (evaluasi).

\section{Pra Siklus}

\section{Planning}

Pada tahap ini, peneliti membuat Rencana Pelaksanaan Pembelajaran (RPP) yang didalamnya memuat seluruh hal yang akan dilakukan dalam pembelajaran, termasuk pemilihan alat, media dan lembar kerja yang digunakan dalam pelaksanaan pembelajaran dengan menggunakan model Konvensional.

\section{Acting}

Dalam tahap tindakan, peneliti mengajar sesuai dengan rencana yang telah dibuat, dalam tahap ini pula peneliti didampingi oleh guru matematika menjadi observer dalam pembelajaran yang dilakukan peneliti.

\section{Observing}

Dilakukan oleh guru matematika sesuai dengan poin-poin pengamatan yang telah dipersiapkan oleh peneliti, baik pengamatan tentang proses pembelajaran, motivasi siswa dan juga keaktifan guru.

\section{Reflecting}

Tahap refleksi adalah tahap untuk menganalisis data yang diperoleh dari hasil tes siswa dan lembar observasi guru matematika. Hasil dari menganalisis data pada tahap ini sangat diperlukan untuk melaksanakan pembelajaran pada siklus berikutnya.

\section{Siklus I}

\section{Planning}

Pada tahap ini, peneliti membuat Rencana Pelaksanaan Pembelajaran (RPP) yang didalamnya memuat seluruh hal yang akan dilakukan dalam pembelajaran, termasuk pemilihan alat, media dan lembar kerja yang digunakan dalam pelaksanaan pembelajaran dengan menggunakan model TPS (Think-Pair-Share).

\section{Acting}

Dalam tahap tindakan, peneliti mengajar sesuai dengan rencana yang telah dibuat, dalam tahap ini pula peneliti didampingi oleh guru matematika menjadi observer dalam pembelajaran yang dilakukan peneliti. 


\section{Observing}

Dilakukan oleh guru matematika sesuai dengan poin-poin pengamatan yang telah dipersiapkan oleh peneliti, baik pengamatan tentang proses pembelajaran, motivasi siswa dan juga keaktifan guru.

\section{Reflecting}

Tahap refleksi adalah tahap untuk menganalisis data yang diperoleh dari hasil tes siswa, lembar kerja siswa dan lembar observasi guru matematika. Hasil dari menganalisis data pada tahap ini sangat diperlukan untuk melaksanakan pembelajaran pada siklus berikutnya.

\section{Siklus II}

Siklus II dilaksanakan berdasarkan hasil refleksi siklus I. Pada siklus II ini, tindakan yang dilakukan bertujuan untuk memperbaiki kekurangan pada siklus I. Kegiatan pada siklus II juga melalui tahapan yang sama seperti siklus I yaitu meliputi perencanaan tindakan (Planning), pelaksanaan tindakan (Acting), pengamatan (Observation), refleksi (Reflecting).

Jika pada akhir siklus II tidak terjadi peningkatan motivasi dan prestasi belajar matematika siswa maka dilaksanakan siklus selanjutnya yang tahapannya sama seperti siklus I dan II. Siklus berhenti ketika sudah terjadi peningkatan motivasi dan prestasi belajar matematika.

Pembelajaran kooperatif tipe TPS (Think-Pair-Share) ini dikatakan berhasil jika: 1) nilai rata-rata kelas minimal 71,2) banyaknya siswa yang mencapai KKM minimal 70\%, 3) banyak siswa yang mempunyai motivasi tinggi minimal $70 \%$. Sehingga pembelajaran matematika di kelas VIIA SMP Negeri 3 Bendosari Sukoharjo semester genap tahun ajaran 2015/2016 dikatakan tuntas dan berhasil.

Analisis data dilakukan dengan membandingkan kondisi akibat suatu siklus dengan akibat siklus sebelumnya dikaitkan pada indikator kinerja. Data mengenai prestasi belajar siswa diambil dari kemampuan kognitif siswa dalam memecahkan masalah dianalisis dengan cara menghitung rata-rata nilai ketuntasan belajar secara klasikal. Adapun rumus yang digunakan adalah:

\section{Menghitung nilai rata-rata kelas}

$$
\bar{x}=\frac{\sum x}{N}
$$

\section{Keterangan:}

$$
\begin{array}{ll}
x & =\text { rata-rata nilai } \\
\sum x & =\text { jumlah seluruh nilai } \\
\mathrm{N} & =\text { banyak siswa }
\end{array}
$$




\section{Menghitung prestasi belajar}

Persentase prestasi belajar $=\frac{\text { Banyaksiswatuntasbelajar }}{\text { Banyakseluruhsiswa }} \times 100 \%$

\section{Data mengenai motivasi belajar}

Motivasi belajar individu

Tabel 1. Kategori Motivasi Siswa

\begin{tabular}{cc}
\hline Rentang Skor $(X)$ & Motivasi Siswa \\
\hline $\mathbf{X}>\boldsymbol{\mu}+\mathbf{0 , 5 \sigma}$ & Tinggi \\
$\boldsymbol{\mu}-\mathbf{0 , 5 \sigma} \leq \mathbf{X} \leq \boldsymbol{\mu}+\mathbf{0 , 5 \sigma}$ & Sedang \\
$\mathbf{X}<\boldsymbol{\mu}-\mathbf{0 , 5 \sigma}$ & Rendah \\
\hline
\end{tabular}

Keterangan:

$$
\begin{aligned}
\mathrm{X} & =\text { rentang skor } \\
\mu & =\text { rata-rata motivasi belajar individu } \\
& =\frac{\text { jumlahnilaisiswa }}{\text { banyaksiswa }} \\
\sigma & =\text { standar deviasi } \\
& =\sqrt{\sigma^{2}} \\
& =\sqrt{\frac{\text { jumlahkuadratnilaisiswa }}{\text { banyaksiswa }}-\frac{(\text { jumlahnilaisiswa })^{2}}{\text { banyaksiswa }}} \\
\mathrm{N} & =\text { banyak siswa }
\end{aligned}
$$

\section{Motivasi belajar kelas}

Persentase pencapaian $(\%)=\frac{n}{N} \times 100 \%$

Keterangan:

$$
\begin{array}{ll}
\mathrm{n} & =\text { siswa dengan motivasi tinggi } \\
\mathrm{N} & =\text { banyak siswa } \\
\% & =\text { tingkat persentase yang diperoleh/dicapai }
\end{array}
$$




\section{HASIL DAN PEMBAHASAN}

\section{Motivasi belajar siswa}

Berdasarkan penelitian dari pra siklus, siklus I, siklus II dan siklus III hasil dari angket untuk mengetahui motivasi belajar dapat dibuat tabel sebagai berikut.

Tabel 2. Persentase Motivasi Belajar Siswa

\begin{tabular}{cccc}
\hline Siklus & Motivasi Tinggi & Motivasi Sedang & Motivasi Rendah \\
\hline Pra & $41 \%$ & $41 \%$ & $17 \%$ \\
I & $52 \%$ & $17 \%$ & $31 \%$ \\
II & $62 \%$ & $7 \%$ & $31 \%$ \\
III & $72 \%$ & $7 \%$ & $21 \%$ \\
\hline
\end{tabular}

Berdasarkan Tabel 2 di atas menunjukkan motivasi belajar tinggi siswa dengan persentase $41 \%$ pada pra siklus meningkat menjadi 52\% pada siklus I. Dari siklus I $52 \%$ meningkat menjadi 52\% pada siklus II dan pada siklus III naik menjadi $72 \%$.

Dengan demikian dapat disimpulkan bahwa penerapan metode think-pair-share dapat meningkatkan motivasi belajar matematika siswa kelas VIIA SMP Negeri 3 Bendosari Kabupaten Sukoharjo Tahun Pelajaran 2015/2016.

\section{Prestasi belajar siswa}

Berdasarkan penelitian dari pra siklus, siklus I, siklus II dan siklus III hasil dari tes untuk mengetahui nilai rata-rata kelas dapat dibuat tabel sebagai berikut.

Tabel 3. Nilai Rata-Rata Kelas VIIA

\begin{tabular}{cc}
\hline Siklus & Nilai Rata-Rata Kelas VIIA \\
\hline Pra & 41 \\
I & 55 \\
II & 65 \\
III & 76 \\
\hline
\end{tabular}


Berdasarkan Tabel 3 di atas, nilai rata-rata kelas VIIA 41 pada pra siklus meningkat menjadi 55 pada siklus I, kemudian meningkat menjadi 65 pada siklus II dan pada siklus III meningkat lagi menjadi 76. Dengan demikian dapat disimpulkan bahwa penerapan metode think-pair-share dapat meningkatkan nilai rata-rata matematika siswa kelas VIIA SMP Negeri 3 Bendosari Kabupaten Sukoharjo Tahun Pelajaran 2015/2016.

Berdasarkan penelitian dari pra siklus, siklus I, siklus II dan siklus III hasil dari tes untuk mengetahui prestasi belajar dapat dibuat tabel sebagai berikut.

Tabel 4. Persentase Prestasi Belajar Siswa

\begin{tabular}{ccc}
\hline Siklus & Banyak Siswa Mencapai Nilai KKM (71) & $\begin{array}{c}\text { Persentase Prestasi Belajar } \\
\text { Siswa (\%) }\end{array}$ \\
\hline Pra & 0 & $0 \%$ \\
I & 4 & $14 \%$ \\
II & 11 & $38 \%$ \\
III & 22 & $76 \%$ \\
\hline
\end{tabular}

Berdasarkan Tabel 4 di atas menunjukkan prestasi belajar siswa dengan persentase $0 \%$ pada pra siklus meningkat menjadi $14 \%$ pada siklus I , kemudian meningkat lagi menjadi $38 \%$ pada siklus II dan pada siklus III naik menjadi $76 \%$.

Dengan demikian dapat disimpulkan bahwa penerapan metode think-pair-share dapat meningkatkan prestasi belajar matematika siswa kelas VIIA SMP Negeri 3 Bendosari Kabupaten Sukoharjo Tahun Pelajaran 2015/2016.

\section{KESIMPULAN DAN SARAN}

Berdasarkan hasil penelitian dapat disimpulkan bahwa penerapan model pembelajaran kooperatif tipe Think-Pair-Share dapat meningkatkan motivasi dan prestasi belajar matematika pokok bahasan segiempat pada siswa kelas VIIA SMP Negeri 3 Bendosari Kabupaten Sukoharjo Tahun Pelajaran 2015/2016. Hal ini dapat dilihat dari persentase hasil angket dan hasil tes siswa. Untuk nilai rata-rata kelas dari pra siklus 41 naik menjadi 55 di siklus I, kemudian meningkat pada siklus II menjadi 65 selanjutnya meningkat lagi pada siklus III menjadi 76. Untuk persentase motivasi belajar tinggi pra siklus sebesar $41 \%$ meningkat pada siklus I menjadi 52\% kemudian meningkat lagi pada siklus II menjadi 62\% selanjutnya meningkat lagi pada siklus III menjadi $72 \%$. Sedangkan untuk persentase prestasi belajar siswa 
dari pra siklus $0 \%$ meningkat pada siklus I menjadi $14 \%$ kemudian meningkat lagi pada siklus II menjadi 38\% selanjutnya meningkat lagi pada siklus III menjadi $76 \%$.

\section{DAFTAR PUSTAKA}

Arikunto, Suharsimi. 2013. Prosedur Penelitian. Jakarta: Rineka Cipta.

Budiyono. 2015. Pengantar Penilaian Hasil Belajar. Jakarta: Rineka Cipta.

Dimyati dan Mudjiono. 2013. Belajar dan Pembelajaran. Jakarta: Rineka Cipta.

Hamdani. 2011. Strategi Belajar Mengajar. Bandung: Pustaka Setia. 